\title{
Anti-pathogenic efficacy of biogenic silver nanoparticles through adherence and biofilm inhibition in multidrug resistant ESKAPE pathogens
}

Mohd Hashim Khan

B S Abdur Rahman Crescent Institute of Science \& Technology

Sneha Unnikrishnan

B S Abdur Rahman Crescent Institute of Science \& Technology

Karthikeyan Ramalingam ( $\nabla$ karthikeyan.sls@crescent.education )

B S Abdur Rahman Crescent Institute of Science \& Technology https://orcid.org/0000-0002-9334-427X

Research article

Keywords: ESKAPE pathogens, biogenic AgNPs, anti-pathogenic activity, Live/dead assay, biofilm formation

Posted Date: November 2nd, 2019

DOl: https://doi.org/10.21203/rs.2.13646/v2

License: (c) (i) This work is licensed under a Creative Commons Attribution 4.0 International License. Read Full License 
The authors have withdrawn this preprint from Research Square 